\title{
Seasonal Variation in Physicochemical Parameters of Lekki Lagoon and the Conservation of Its Ecosystem
}

\author{
Isaiah 0. Opadokun*, A. E. Falaye, E. K. Ajani \\ Department of Aquaculture and Fisheries Management, University of Ibadan, Ibadan, Nigeria \\ Email: "opadokundipo@gmail.com
}

Received 23 September 2015; accepted 6 November 2015; published 9 November 2015

Copyright (C) 2015 by authors and Scientific Research Publishing Inc.

This work is licensed under the Creative Commons Attribution International License (CC BY). http://creativecommons.org/licenses/by/4.0/

(c) (i) Open Access

\begin{abstract}
Some physicochemical parameters like temperature, transparency, dissolved solid, suspended materials, turbidity, conductivity, $\mathrm{pH}$, total alkalinity, dissolved oxygen, nitrate, phosphate and salinity of water samples collected at Lekki Lagoon from November 2010 to September 2012 were evaluated. Fifteen locations were selected for water sampling according to the activities that took place in the lagoon. Physical water quality parameters such as temperature, transparency, total dissolved solids and total suspended solid showed strong seasonal and spatial fluctuation. Parameters like conductivity, $\mathrm{pH}$ and total alkalinity had relatively constant values among stations though they varied seasonally. Dissolved oxygen, nitrate and phosphate values were within permissible range for fish. Higher salinity values were recorded in wet seasons than dry seasons suggesting that salinity variation at Lekki Lagoon was due to salt incursion from the adjourning Lagos Lagoon and Mahin Creek during rainy season rather than evaporation factor. Salinity range of 1.70 6.00 psu recorded in this study also shows that Lekki Lagoon is tending towards brackish and this may affect the ichthyofauna composition of the lagoon.
\end{abstract}

\section{Keywords}

Water Quality Parameters, Brackish, Spatial Fluctuation, Ichthyofauna

\section{Introduction}

Larger percentage of fish being consumed in the country comes from brackish-marine environment [1]. Conditions of the lagoon environment differ greatly from that of the freshwater environment due to continuous varia-

"Corresponding author.

How to cite this paper: Opadokun, I.O., Falaye, A.E. and Ajani, E.K. (2015) Seasonal Variation in Physicochemical Parameters of Lekki Lagoon and the Conservation of Its Ecosystem. Journal of Geoscience and Environment Protection, 3, 11-17. http://dx.doi.org/10.4236/gep.2015.39002 
tion in the physiochemical and hydrological characteristics of the brackish environment.

Lekki Lagoon, located in Lagos and Ogun states of Nigeria covers an area of nearly $247 \mathrm{~km}^{2}$ and lies between longitude $4^{\circ} 00^{\prime} \mathrm{E}$ and $4^{\circ} 15^{\prime} \mathrm{E}$ and latitude $6^{\circ} 22^{\prime} \mathrm{N}$ and $6^{\circ} 37^{\prime} \mathrm{N}$ [2] [3]. Lagos Lagoon links Lekki Lagoon at the upper part while Mahin creeks link the lagoon at the lower part. River Oni flows into Lekki Lagoon in the north eastern side while Rivers Oshun and Saga flow in from the north western parts [4] [5]. The lagoon is surrounded by many beaches.

Lekki Lagoon is the most important source of affordable animal protein in the form of fish in Epe and IbejuLekki Local Government Areas of Lagos State [6]. This lagoon is the most important source of freshwater fish in Lagos State. The fishery is diverse, highly dispersed and fragmented with about 35 landing sites and more than 3000 fisherfolks [6]. The main occupation of the people in the surrounding communities of the lagoon is fishing [7].

The mean depth of Lekki Lagoon is $3.1 \mathrm{~m}$, and the maximum depth is $6.4 \mathrm{~m}$ at low tide [3] [4] [8]. The highest salinity recorded for Lekki Lagoon in 1981 was 0.3 psu [9] which had made some authors to describe the lagoon as fresh [4] [10]. However, recent works [11] on Lekki Lagoon between year 2006 and 2008 recorded fifty-six fish species that had fresh water origin, ten species of marine water origin and eleven species that were of euryhaline origin and concluded that this lagoon formed a link between the brackish and freshwater systems. There is a possibility that changes in the physicochemical parameters of the water among others things are responsible for the changes in the fish species composition of the lagoon. Since there is paucity of information on the current physicochemical composition of the lagoon and its possible influence on the conservation of the ichthyofauna composition of the lagoon, this study becomes imperative.

\section{Materials and Methods}

The study area, Lekki Lagoon (Figure 1) was monitored from November 2010 to September 2012. Bimonthly field trips were embarked on to collect water samples between the morning hour 9.00 a.m. and 10.00 a.m. in order to determine the physicochemical parameters at the marked sampling points in Figure 1. The following physico-chemical parameters were investigated: temperature, transparency, total dissolved solid, total suspended

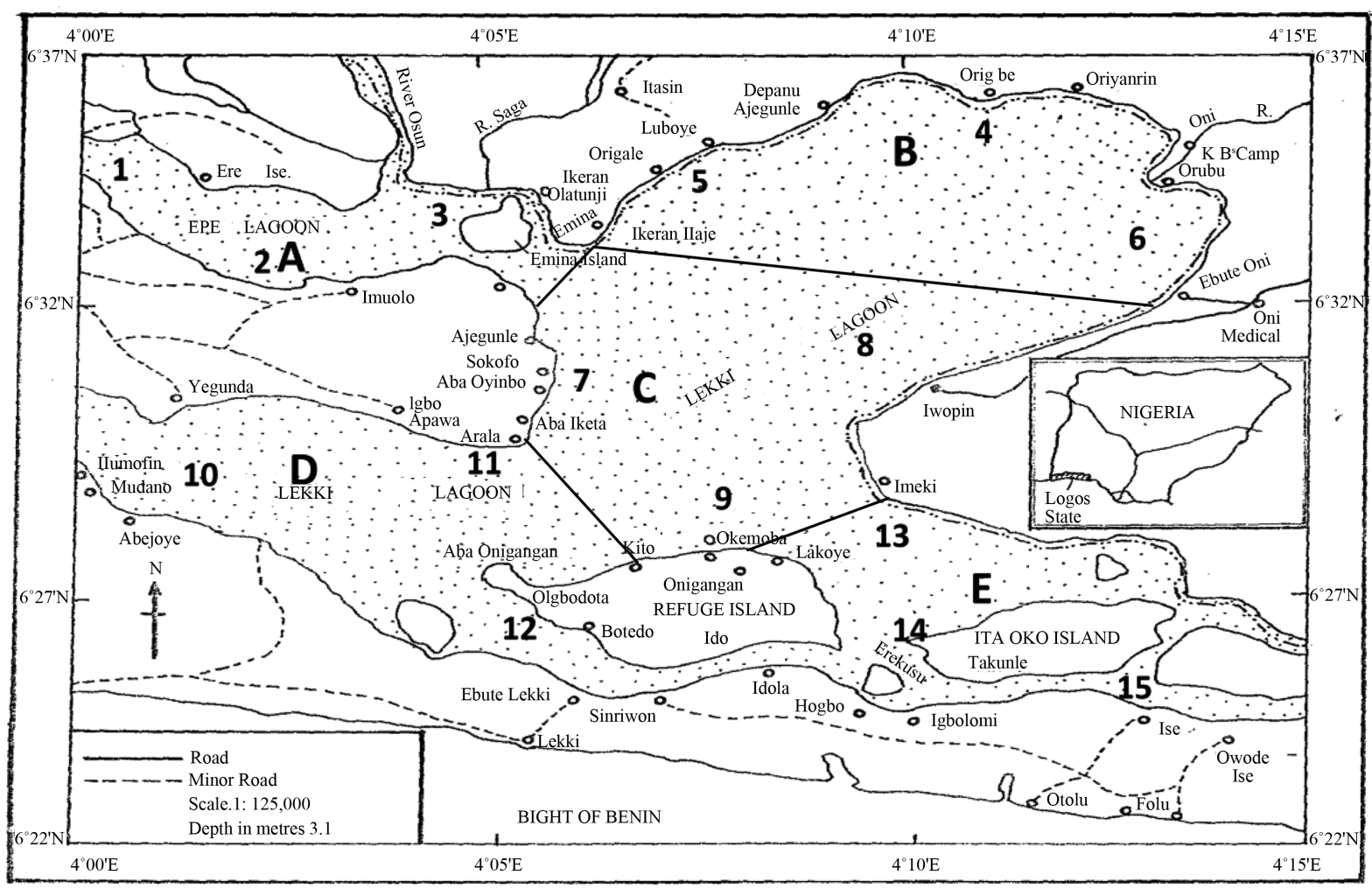

Figure 1. Map of Lekki Lagoon showing Sampling Stations. 
solid, turbidity, conductivity, $\mathrm{pH}$, total alkalinity, dissolved oxygen, nitrate, phosphate and salinity. The analysis was done using a combination of in situ and laboratory method [12].

The sampling methods were time and space stratified. Time stratification covered two dry seasons and two wet seasons. Space stratification was based on the method of Ajani [13] in which the entire lagoon was divided into five zones-mouth, upper, middle, lower and head. Three sampling stations were chosen in each of the five zones giving a total of fifteen sampling stations within the lagoon (Figure 1). The sampling stations were located using bearings such as major landing sites, shoreline features, fishermen poles and wrecks on the lagoon. The exact sampling locations were fixed using Global Positioning System (GPS) as stated in Table 1.

Basic statistical analyses such as means, range, standard deviation, t-test and probability levels were used to test the physicochemical parameter data of Lekki Lagoon. One way and two ways analysis of variance were used to find level of significance on seasonal variation while water quality parameters were subjected to Chisquare test of homogeneity.

\section{Results and Discussion}

Temperature was relatively high during the study period with a mean of $28.73^{\circ} \mathrm{C} \pm 1.83^{\circ} \mathrm{C}$. This may be due to the shallow nature of Lekki Lagoon (3.0 - $6.4 \mathrm{~m}$ ) according to Kusemiju [8], which permits the heat of the sun to penetrate deep into the water as well as the regular tidal motion of the lagoon. A similar trend was observed on Lagos Lagoon by Ajani [13]. Dry seasons' temperatures were slightly higher than the wet seasons although the fluctuation was just $1.03^{\circ} \mathrm{C}$ and $0.33^{\circ} \mathrm{C}$ in the first and second sampling years respectively. Actually this agrees with earlier works [13]-[15] who asserted a slight variation of about $0.5^{\circ} \mathrm{C}$ only in the dry and wet seasons' temperature of the lagoon of Southwestern Nigeria.

Temperature range recorded for the sampling period was $26.5^{\circ} \mathrm{C}-32.1^{\circ} \mathrm{C}$. This is similar to observation of Lawal-Are [16] who recorded a temperature range of $26.5^{\circ} \mathrm{C}-31.2^{\circ} \mathrm{C}$ for Lekki Lagoon, The relatively small temperature range observed in this study also tallied with the observations of some authors [6] [9] [13]. They all noticed that the temperature is a stable environmental factor in the shallow brackish environments of West Africa.

Turner and Millward [17] stated the importance of water transparency in the Lagoons as a main determinant factor of the condition and productivity of an aquatic system and the docility of water for human consumption and recreation. Mean water transparency recorded for the sampling period was $0.65 \pm 0.08 \mathrm{~m}$ with a range of $0.40-0.80 \mathrm{~m}$. This range was higher than the observation of Lawal-are [16] who recorded a transparency range

\section{Table 1. GPS location of sampling stations.}

\begin{tabular}{cccc}
\hline s/n & Zone & Sampling station & Gps coordinates \\
\hline 1 & A & Ere ise & $06^{\circ} 34.753^{\prime} \mathrm{N} / 004^{\circ} 01.525^{\prime} \mathrm{E}$ \\
2 & A & Imogo & $06^{\circ} 32.690^{\prime} \mathrm{N} / 004^{\circ} 04.232^{\prime} \mathrm{E}$ \\
3 & A & Emina & $06^{\circ} 32.765^{\prime} \mathrm{N} / 004^{\circ} 04.972^{\prime} \mathrm{E}$ \\
4 & B & Origbe & $06^{\circ} 35.690^{\prime} \mathrm{N} / 004^{\circ} 10.845^{\prime} \mathrm{E}$ \\
5 & B & Iluboye & $06^{\circ} 34.292^{\prime} \mathrm{N} / 004^{\circ} 07.772^{\prime} \mathrm{E}$ \\
6 & Ebute oni & $06^{\circ} 32.004^{\prime} \mathrm{N} / 004^{\circ} 13.313^{\prime} \mathrm{E}$ \\
7 & Aba oyinbo & $06^{\circ} 30.487^{\prime} \mathrm{N} / 004^{\circ} 05.894^{\prime} \mathrm{E}$ \\
8 & C & Iwopin & $06^{\circ} 30.614^{\prime} \mathrm{N} / 004^{\circ} 10.259^{\prime} \mathrm{E}$ \\
9 & C & Onigangan & $06^{\circ} 27.472^{\prime} \mathrm{N} / 004^{\circ} 08.214^{\prime} \mathrm{E}$ \\
10 & Ilumofin & $06^{\circ} 29.478^{\prime} \mathrm{N} / 004^{\circ} 01.009^{\prime} \mathrm{E}$ \\
11 & C & Arala & $06^{\circ} 29.750^{\prime} \mathrm{N} / 004^{\circ} 05.523^{\prime} \mathrm{E}$ \\
12 & D & Batedo & $06^{\circ} 26.443^{\prime} \mathrm{N} / 004^{\circ} 06.212^{\prime} \mathrm{E}$ \\
13 & D & Lakoye & $06^{\circ} 27.621^{\prime} \mathrm{N} / 004^{\circ} 08.743^{\prime} \mathrm{E}$ \\
14 & D & Takunle & $06^{\circ} 25.757^{\prime} \mathrm{N} / 004^{\circ} 11.234^{\prime} \mathrm{E}$ \\
15 & E & Ise & $06^{\circ} 25.011^{\prime} \mathrm{N} / 004^{\circ} 12.865^{\prime} \mathrm{E}$ \\
\hline
\end{tabular}


of 0.10 to $0.47 \mathrm{~m}$ on the same Lekki Lagoon, but in line with works of Kusemiju [8] and Emmanuel [18] who recorded a range of $0.52-1.04 \mathrm{~m}$ and $0.80-2.13 \mathrm{~m}$ respectively. Different readings by all these authors are directly related to the rainfall pattern during the sampling period. Notwithstanding, all these previous works agreed with this study that higher transparency was recorded in dry season and lowest transparency in the rainy season. This could be attributed to higher turbidity during the wet season caused by the discharge of rain water into the Lekki Lagoon which brings debris, suspended particles and disturbance at the bottom [8].

Total dissolved solid (TDS) and Total suspended solid (TSS) were both higher in the wet season than the dry season. High values of TDS and TSS must have contributed greatly to the low transparency experienced during wet season. Ajani [13] who also recorded low transparency in Lagos Lagoon during wet season attributed this to high quantity of suspended solid materials washed into the lagoon by the run-off from the surrounding rivers. Although this was contrary to the findings of Emmanuel [18] who recorded a higher TDS for dry season than wet season in Lagos Lagoon and attributed this to the proximity of Lagos Lagoon to the sea. Both TDS and TSS had negative correlation with transparency $r=-0.26$ and -0.28 for both TDS and TSS respectively.

In this study, turbidity was lowest in the dry season (6 NTU) and had highest value in the rainy season (22 NTU). Thus, turbidity and transparency had an inverse relationship. This was in line with the work of Babalola [19] on Kuramo Lagoon in Lagos state who stated that the higher the turbidity, the lower the transparency, and vice versa.

Water conductivity is a measure of the concentration of dissolved solids in water and it gives an indirect dissolved salt content of fluid. The mean water conductivity for the sampling period was $133.41 \pm 15.32 \mu \mathrm{Scm}^{-1}$ with a range of $94-160 \mu \mathrm{Scm}^{-1}$. The lowest water conductivity $\left(94.00 \mu \mathrm{Scm}^{-1}\right)$ was recorded in May 2011 at the onset of rainy season in Station 3; while the highest conductivity reading $\left(160 \mu \mathrm{Scm}^{-1}\right)$ was recorded in September, 2012 at Station 7. Lagoon was relatively rough at this period. A weak positive correlation exist between conductivity and total dissolved solid content of the water $(r=0.22)$ during the period under review. Seasonal variations in the lagoon water conductivity was significant $(\mathrm{P}<0.05)$, whereas spatial variations was not.

Washington State Department of Ecology [20] reported a conductivity of $56,000 \mu \mathrm{Scm}^{-1}$ for sea water and stated that conductivity is an indirect index of water hardness. $6-25 \mu \mathrm{Scm}^{-1}$ was reported for conductivity in Cross River System [21], $44-96 \mu \mathrm{Scm}^{-1}$ for River Oshun [22] and $46-96 \mu \mathrm{Scm}^{-1}$ in the upper Niger River [23], respectively. Emmanuel [18] reported a conductivity mean value of $27500 \mu \mathrm{Scm}^{-1}$ for wet season in Lagos Lagoon and $51,400 \mu \mathrm{Scm}^{-1}$ for dry season because of the lagoon proximity to the sea. He however recorded 466.0 $\mu \mathrm{Scm}^{-1}$ for Lekki Lagoon in dry season, a value which was higher than the one obtained in this study. Babalola and Agbebi [19] reported that the conductivity of Kuramo Lagoon water fluctuate from $582 \mu \mathrm{Scm}^{-1}$ in wet season to $820 \mu \mathrm{Scm}^{-1}$ in dry season.

$\mathrm{pH}$ is a measure of the acidity or basicity of an aqueous solution. An aqueous solution with $\mathrm{pH}$ value less than 7 is classified as acidic while the one with a pH value greater than 7 is said to be basic or alkaline. The pH varied between 5.00 and 8.00 with a mean of $6.45 \pm 0.89$ during the sampling period. This range falls within permissible range for fish culture. The lowest water $\mathrm{pH}$ was 5.00 and it was recorded in January 2012 at the peak of dry season in Stations 2 and 4; while the highest $\mathrm{pH}$ reading (8.00) was recorded in May and July, 2011 at the peak of rainy season. Seasonal $\mathrm{pH}$ variation was significant $(\mathrm{P}<0.05)$ whereas there was no significant difference $(\mathrm{P}>0.05)$ in the mean water $\mathrm{pH}$ among different Stations. $\mathrm{pH}$ is a very important physicochemical parameter that influences fish performance in water. Several fish will stop growing at a lethal $\mathrm{pH}$ and eventually die off in extreme cases.

The measurement of the capacity of water to neutralize acids is referred to as alkalinity [24]. The value of total alkalinity of a water body is very important in determining the ability of such water body to neutralize acidic pollution from waste water, industrial effluents or rainfall. Total alkalinity value for the sampling period ranged between $16.0-45.0 \mathrm{mg} / \mathrm{L}$ with a mean of $20.90 \pm 5.70 \mathrm{mg} / \mathrm{L}$. Wet seasons recorded higher alkalinity values than dry seasons; this may be due to run offs from surrounding rocks and soils during rainfall as well as certain plant activities [24]. Mean total alkalinities for 2010-2011 and 2011-2012 wet seasons respectively were 17.90 \pm 1.13 $\mathrm{mg} / \mathrm{L}$ and $26.38 \pm 9.32 \mathrm{mg} / \mathrm{L}$. Dry seasons total alkalinities values were $19.73 \pm 0.81 \mathrm{mg} / \mathrm{L}$ and $19.58 \pm 0.77$ $\mathrm{mg} / \mathrm{L}$ for 2010-2011 and 2011-2012 sampling periods respectively. Seasonal variation was significant $(\mathrm{P}<0.05)$ while spatial variation was not $(\mathrm{P}>0.05)$.

The dissolved oxygen (DO) range for the study period was $4.7-8.0 \mathrm{mg} / \mathrm{L}$. This value still falls within acceptable range for optimal performance of fish. DO ranges of $4.9-11.2 \mathrm{mg} / \mathrm{L}, 4.0-11.2 \mathrm{mg} / \mathrm{L}$ and $5.2-11.8$ $\mathrm{mg} / \mathrm{L}$ were reported for Badagry, Lagos and Lekki Lagoons respectively [16]; whereas a range of $4.03-8.93$ 
$\mathrm{mg} / \mathrm{L}$ was reported for Lagos Lagoon [13]. Thus it appear as if DO is usually high in lagoon probably due to constant tidal waves that ensures mixing of lagoon water, thereby constantly exposing the bottom water to atmospheric oxygen thus ensuring constant diffusion of atmospheric oxygen into the lagoon water.

Fluctuation in the DO was much in the second sampling year (2011-2012) than the first sampling year (2010-2011). Likewise, DO values for the wet seasons were higher than the dry seasons (Table 2), an observation similar to what was reported on Lagos Lagoon [13]. These relationships between the DO and rainfall pattern could be as a result of highly oxygenated rainwater that mix with the lagoon water during wet season thus increasing the DO content of the lagoon water. Babalola and Agbebi [19] state that during the dry season, the dissolved oxygen escaped to the atmosphere from the surface of Kuramo Lagoon water due to high temperature because oxygen is sensitive to high temperature. During this period, according to them, aquatic plants compete for dissolved oxygen in the water for respiration although this can be gotten back as a product of photosynthesis during the day time. During the wet season however, the dissolved oxygen in Kuramo Lagoon increased as a result of dissolved atmospheric oxygen from rain water and high wind current.

Phosphate and nitrate did not show distinct seasonal variation but did show spatial variation. Highest value of Nitrate $0.39 \pm 0.22 \mathrm{mg} / \mathrm{L}$ and Phosphate $0.36 \pm 0.18 \mathrm{mg} / \mathrm{L}$ were recorded in Zone E while Zone A had the lowest Nitrate $0.18 \pm 0.15 \mathrm{mg} / \mathrm{L}$ and Phosphate $0.15 \pm 0.09 \mathrm{mg} / \mathrm{L}$. Nitrate $0.12 \pm 0.02-0.48 \pm 0.15 \mathrm{mg} / \mathrm{L}$ and phosphate $0.14 \pm 0.09 \mathrm{mg} / \mathrm{L}-0.29 \pm 0.14 \mathrm{mg} / \mathrm{L}$ were recorded in dry and wet seasons respectively. Bulk of the nitrogen might be from agricultural fields or deposition of raw sewage into the lagoon while phosphate addition could be from detergent rich sewage effluents. Phosphate and nitrate showed almost positive relationship in all locations and the relationship was significant.

Salinity range for the study period was between 1.70 and $6.00 \mathrm{psu}$. The lowest salinity (1.7 psu) was recorded in November 2011 at Station 5 while the highest salinity (6.00 psu) was obtained at Station 13 in July 2011. The highest salinity recorded by Kusemiju [9] for Lekki Lagoon was 0.3 psu and Williams [25] as cited by Trewavas [10] and Fawole [4] described the lagoon as fresh. However, this recent study confirms the works of Lawal-Are [16] and Emmanuel [18] who reported a range of 0.00 to 3.10 psu and 0.007 to 4.70 psu respectively for Lekki Lagoon. They identified two major sources of saline water incursion into Lekki Lagoon which were Lagos Lagoon and Mahin Creek. Waljeski [26] in a similar work on Rodeo Lagoon in California reported salt water intrusion into Rodeo Lagoon by subsurface flow through the barrier beach from the ocean and leaching of ions through lagoon bottom sediments.

The seasonal salinity variation during the wet and dry seasons was quite high (Table 2). Analysis of the seasonal salinity variation showed that the mean salinity for dry seasons were $2.53 \pm 0.47$ psu and $2.63 \pm 0.63$ psu in 2010-2011 and 2011-2012 sampling periods respectively while wet seasons mean values were $3.83 \pm 0.93$ psu

Table 2. Means of the major physicochemical parameters recorded in the two sampling years (2010-2011 and 2011-2012).

\begin{tabular}{|c|c|c|c|c|}
\hline \multirow{2}{*}{ Parameters } & 2010-2011 & 2011 & 2011-2012 & 2012 \\
\hline & Dry & Wet & Dry & Wet \\
\hline Temperature $\left({ }^{\circ} \mathrm{C}\right)$ & $28.33 \pm 0.91$ & $27.30 \pm 1.74$ & $29.80 \pm 1.32$ & $29.47 \pm 2.01$ \\
\hline Transparency (m) & $0.71 \pm 0.04$ & $0.60 \pm 0.90$ & $0.70 \pm 0.03$ & $0.61 \pm 0.08$ \\
\hline Salinity (psu) & $2.53 \pm 0.47$ & $3.83 \pm 0.93$ & $2.63 \pm 0.63$ & $4.43 \pm 0.52$ \\
\hline Dissolved oxygen (mg/L) & $6.33 \pm 0.40$ & $6.63 \pm 0.45$ & $5.98 \pm 0.65$ & $4.43 \pm 0.52$ \\
\hline $\mathrm{pH}$ & $5.68 \pm 0.38$ & $7.08 \pm 0.82$ & $5.96 \pm 0.55$ & $7.07 \pm 0.65$ \\
\hline Nitrate (mg/L) & $0.18 \pm 0.04$ & $0.39 \pm 0.15$ & $0.20 \pm 0.09$ & $0.52 \pm 0.28$ \\
\hline Phosphate (mg/L) & $0.16 \pm 0.03$ & $0.37 \pm 0.16$ & $0.22 \pm 0.10$ & $0.29 \pm 0.13$ \\
\hline Total alkalinity (mg/L) & $19.73 \pm 0.81$ & $17.90 \pm 1.13$ & $19.58 \pm 0.77$ & $26.38 \pm 9.32$ \\
\hline Conductivity $\left(\mu \mathrm{Scm}^{-1}\right)$ & $131.67 \pm 7.05$ & $126.33 \pm 20.50$ & $125.23 \pm 5.99$ & $150.40 \pm 5.63$ \\
\hline Total dissolved solid (mg/L) & $48.82 \pm 5.63$ & $52.07 \pm 8.13$ & $46.67 \pm 3.07$ & $45.66 \pm 6.70$ \\
\hline Total suspended solid (mg/L) & $44.83 \pm 4.21$ & $50.17 \pm 8.07$ & $45.07 \pm 3.09$ & $43.57 \pm 7.37$ \\
\hline Turbidity (m) & $11.83 \pm 1.89$ & $16.00 \pm 3.26$ & $11.67 \pm 2.37$ & $13.50 \pm 3.70$ \\
\hline
\end{tabular}


and $4.43 \pm 0.52$ psu for years 2010-2011 and 2011-2012 respectively. These suggest that the inflow of water from Lagos Lagoon and Mahin Creek in the rainy season was the main source of increase in salinity level at Lekki Lagoon. Indeed, Lawal-Are [16] concluded that it would appear that Lekki Lagoon is beginning to experience a low brackish water regime instead of being completely fresh water.

Salinity as an important ecological factor has been known to have a great effect on the biotic life in aquatic ecosystem because each fish species has a salinity range where they can operate. Blaber [27] reported that egg development of some fish species occurred at certain salinity ranges and any departure from such ranges will have serious negative effect on the growth and development of the fish. Thus, freshwater fish species like Gymnarchus niloticus, Mormyrus rume and Parachana obscura which are predominant in Lekki Lagoon [11] could have their existence in the lagoon threatened if the saltwater incursion into the lagoon should continue. ANOVA showed that although the seasonal variation was significant ( $<<0.05$ ), spatial variation (among different stations) was insignificant $(\mathrm{p}>0.05)$. This means that there were not much variation in the salinity values at different sampling locations during the sampling period although much variation existed within the sampling months (period).

\section{Conclusions}

This study confirms stability in the physical and chemical factors of Lekki Lagoon. The spatial distributions were relatively stable while there was a distinct seasonal variation in most cases. The highest salinity value of 6.00 psu recorded in this study is more than the highest values reported by earlier works which are 0.3 psu, 3.10 psu and 4.70 psu respectively [9] [16] [18]. This could mean that Lekki Lagoon is now experiencing a low brackish water regime instead of being completely fresh water. This brackish level tends to be increasing every year apparently due to continuous saline water incursion from the two ends of the lagoon-Lagos Lagoon and Mahin Creek. This would eventually change the ichthyofauna composition of the lagoon.

There should be regular monitoring and study of the physical and chemical state of the Lekki Lagoon environment in order to provide a basis for an informed decision on sustainable management of the lagoon.

\section{References}

[1] FAO (1995) FAO Yearbook: Fishery Statistics—Catches and Landings 1993. Vol. 76. Food and Agriculture Organization of the United Nations, Rome, Italy, $687 \mathrm{p}$.

[2] Opadokun, I.O and Ajani, E.K. (2015) Some Aspects of the Reproductive Biology of Gymnarchus niloticus Cuvier, 1829 (Knifefish) in Lekki Lagoon, Nigeria. International Journal of Fisheries and Aquatic Studies, 2, 166-170.

[3] Akinsanya B., Otubanjo, O.A. and Ibidapo, C.A. (2007) Helminth Bioload of Chrysichthys nigrodigitatus (Lacepede 1802) from Lekki Lagoon Lagos, Nigeria. Turkish Journal of Fisheries and Aquatic Science, 7, 83-87.

[4] Fawole, O.O. (2002) Morphometry and Diet of Momyrus rume in the Lekki Lagoon Lagos, Nigeria. International Journal of Tropical Biology and Conservation, 50, 689-694.

[5] Kuton, M.P. (2006) The Biology of Cichlid Fishes from Badagry, Lagos and Lekki Lagoons, Southwest Nigeria. Ph.D. Dissertation, University of Lagos, Lagos.

[6] Emmanuel, B.E (2009) The Artisanal Fishing Gears, Crafts Technology and Their Efficiency in the Lekki Lagoon, Nigeria. Ph.D. Dissertation, University of Lagos, Lagos.

[7] Lagos State Facts and Figures (1996) No 20, Akinlade L. Ed. 30 p.

[8] Kusemiju, K. (1973) A Study of the Catfishes of Lekki Lagoon with Particular Reference to the Species Chrysichthys walkeri (Bagridae). Ph.D. Dissertation, University of Lagos, Lagos.

[9] Kusemiju, K. (1981) The Hydrobiology and Fishes of the Lekki Lagoon, Nigeria. Nigerian Journal of Natural Sciences, 3, 135-145.

[10] Trewavas, E. (1983) Tilapine Fishes of the Genera Sarotherodon, Oreochromis and Danakilia. London British Museum (Natural History), 583 p.

[11] Emmanuel, B.E. and Osibona, A.O. (2013) Ichthyofauna Characteristics of a Tropical Low Brackish Open Lagoon in South-Western Nigeria. International Journal of Fisheries and Aquaculture, 5, 122-135.

[12] APHA (1998) Standard Methods for the Examination of Water and Wastewater. 20th Edition, American Public Health Association, Washington DC.

[13] Ajani, E.K. (2000) Effects of Biotic and Abiotic Components of the Habitat on Fish Productivity in Lagos, Nigeria. PhD Dissertation, University of Ibadan, Ibadan. 
[14] Olaniyan, C.I.O. (1969) The Seasonal Variations in the Hydrography and Total Plankton of the Lagoons of Southwest Nigeria. Nigerian Journal of Science, 3, 101-119.

[15] Ajao, E.A. (1990) The Influence of Domestic and Industrial Effluents on Populations of Sessile and Benthic Organisms in Lagos Lagoon. PhD Dissertation, University of Ibadan, Ibadan.

[16] Lawal-Are, A.O. (2001) Aspects of the Biology of the Lagoon Crab, Callinectes amnicola (Derocheburne) in Badagry, Lagos and Lekki Lagoons, Nigeria. Journal of Scientific Research and Development, 5, 215-220.

[17] Turner, A. and Millward, G.E. (2002) Suspended Particles: Their Role in Estuarine Biogeochemical Cycles. Estuarine, Coastal and Shelf Science, 55, 857-883. http://dx.doi.org/10.1006/ecss.2002.1033

[18] Emmanuel, B.E. and Chukwu, L.O. (2010) Spatial Distribution of Saline Water and Possible Sources of Intrusion into a Tropical Freshwater Lagoon and the Transitional Effects on the Lacustrine Ichthyofaunal Diversity. African Journal of Environmental Science and Technology, 4, 480-491.

[19] Babalola, O.A. and Agbebi, F.O. (2013) Physico-Chemical Characteristics and Water Quality Assessment from Kuramo Lagoon, Lagos, Nigeria. Society for Science and Nature, 3, 98-102.

[20] Washington State Department of Ecology (1991) Lakes: Temperature in Lakes. In: Blaber, S.J.M., Ed., A Citizen’s Guide to Understanding and Monitoring Lakes and Streams, Fish and Fisheries of Tropical Estuaries, Chapman Hall, London, 367. http://www.ecy.wa.gov/programs/wq/plants/management/joysmanual/temperature.html

[21] Akinrotimi, O.A. and Edun, O.M. (2013) Impact of Climate Change on Brackish Water Aquaculture Development in the Coastal Areas of the Niger Delta. Proceedings of the 28th Annual Conference of the Fisheries Society of Nigeria, Abuja, 25-28 November 2013, 140-145.

[22] Egborge, B.M. (1979) The Effect of Impoundment on the Water Chemistry of Lake Asejire, Nigeria. Freshwater Biology, 9, 403-412. http://dx.doi.org/10.1111/j.1365-2427.1979.tb01525.x

[23] Welcomme, R.L. (1985) River Fisheries. FAO Technical Paper No. 262, Rome, 320 p.

[24] United States Environmental Protection Agency (USEPA) (2012) Total Alkalinity, Monitoring and Assessment. http://water.epa.gov/type/rsl/monitoring/vms510.cfm

[25] Williams, N.V. (1962) The Seasonal Distribution of the Teleost Fauna in Lagos Harbor, Creek and Lagoon in Relation to Salt Tolerance. M.Sc. Thesis, University College of North Wales, Bangor.

[26] Waljeski, C.A. and Williams, J.L. (2004) Spatial Distribution and Possible Sources of Saline Waters in Rodeo Lagoon, Golden Gate National Recreation Area, Mavin County, California. Water Resources Center, Archives, 23.

[27] Blaber, S.J.M. (1997) Fish and Fisheries of Tropical Estuaries. Chapman Hall, London, 367. 